
\title{
THE EFFECT OF HEAT APPLICATION ON FLUORIDE RELEASE FROM
ANTIBACTERIAL AGENT ADDED GLASS IONOMER CEMENT
}

\section{ABSTRACT}

Objectives: This study aimed to evaluate the effect of heat on the fluoride $\left(\mathrm{F}^{-}\right)$releasing ability of glass ionomer cement (GIC) when used in the conventional form and when combined with $5 \%$ cetylpryridium chloride (CPC).

Materials and Methods: Twenty ( $n=5$; each group) GIC samples were prepared, with the experimental group comprising GIC combined with 5\% CPC and the control group comprising GIC without 5\% CPC. The samples were prepared by non-heating (NH) procedures $(n=10)$ or by heating $(H)$ for 60 seconds $(n=10)$ with a Light Emitting Diode (LED). Flouride releasing pattern was evaluated on days 1, 7, 15 and 30. Repeated measurements using two-way ANOVA and Fisher's LSD test were used for comparisons $(\mathrm{p}<0.05)$.

Results: Interactions among the groups, application of heat, and the time at which $\mathrm{F}^{-}$ release was evaluated were analyzed $(\mathrm{p}<0.001)$. There was no significant difference in $\mathrm{F}^{-}$release in the $\mathrm{NH}$ control and experimental groups on days 1, 7 and 15; however a significant release was evident in the experimental group on day $30(\mathrm{p}=0.01)$. Significantly higher values were obtained in the $\mathrm{H}$ associated control group than in the experimental group on days $1(\mathrm{p}=0.026), 7(\mathrm{p}=0.001), 15(\mathrm{p}=0.005)$ and $30(\mathrm{p}=0.028)$. Significantly increased values were obtained from days 1 to 30 by $\mathrm{NH}$ and $\mathrm{H}$ procedures for both the groups $(\mathrm{p}<0.001)$.

Conclusions: Heating in the control and experimental groups showed an increased $\mathrm{F}^{-}$ releasing pattern. The fluoride release on 60 seconds of heating GIC containing 5\% $\mathrm{CPC}$, can have acceptable values for up to 30 days. The increased $\mathrm{F}^{-}$releasing pattern after the heating is believed to be promising for antibacterial GIC combinations.

Key words: Anti-bacterial agents, glass ionomer cement, fluorides, heating.

\author{
(D)*Ayça Kurt $^{1}$ \\ (D) Tamer Tüzüner ${ }^{2}$ \\ (D) İkay Altıntepe ${ }^{3}$ \\ (iD) Sema Aydınoğlu ${ }^{1}$ \\ (D) Münevver Sökmen ${ }^{4}$
}

ORCID IDs of the authors: A.K. 0000-0003-4762-7495

T.T. 0000-0001-5817-5928

İ.A. 0000-0002-2630-5254

S.A. $0000-0003-1490-8645$

M.S. 0000-0002-7671-4160

1 Deparment of Pedodontics, Faculty of Dentistry, Recep Tayyip Erdoğan University, Rize, Turkey

2 Department of Pedodontics, Faculty of Dentistry, Karadeniz Technical University, Trabzon, Turkey

3 Department of Pedodontics, Faculty of Dentistry, Akdeniz University, Antalya, Turkey

${ }^{4}$ Bioengineering Department, Faculty of Engineering Architecture, Konya Gida ve Tarım University, Konya, Turkey

$\begin{array}{ll}\text { Received } & : 26.12 .2018 \\ \text { Accepted } & : 01.04 .2019\end{array}$

How to Cite: Kurt A, Tüzüner T, Altıntepe İ, Aydınoğlu S, Sökmen M. The Effect of Heat Application on Fluoride Release From Antibacterıal Agent Added Glass Ionomer Cement. Cumhuriyet Dent J 2019;22:2:218-225.

Deparment of Pedodontics, Faculty of Dentistry, Recep Tayyip Erdoğan University, Rize, Turkey

Phone: +90 5065863909 E-mail: kurtayca23@gmail.com 


\section{INTRODUCTION}

Although dental caries is one of the most common oral diseases worldwide, it can neither be treated completely in the underdeveloped societies nor can become a priority in the developing and industrialized countries over social, economic, political and other issues. ${ }^{1,2}$ According to Blinkhorn and Davies, ${ }^{3}$ the main reasons for inability to provide dental care are expensive dental equipment and inability to meet the demand for a highly trained staff. In 1994, the atraumatic restorative treatment technique (ART) was discovered by the World Health Organization to overcome these difficulties. ${ }^{4}$ In ART, which is a form of mostly painless restorative treatment, cavitations are restored with a biocompatible material that does not cause bacterial invasion. Glass ionomer cement (GIC) is generally preferred for this treatment because of its chemical attachment to enamel and dentin, fluoride release and the ease of use. ${ }^{5}$ Despite numerous advantages of GIC as a restorative material, it has a few disadvantages in terms of secondary cavities and poor mechanical properties. ${ }^{6}$

There are numerous methods with modified properties used to overcome the disadvantageous of GIC. Materials such as routine hydroxyapatite, bioactive glass and strontium have been added to improve the physical and antibacterial (AB) properties of GIC. ${ }^{7-9}$ It has been reported ${ }^{10,11}$ that bactericidal materials such as chlorhexidine (CHX), have been used in a variety of studies, in which the $A B$ efficiency of GICs has been observed to increase. In addition, the use of materials such as cetrimide (CT ), cetylpyridinium chloride (CPC) and benzalkonium chloride (BC) from quaternary ammonium compounds (QAC) in combination with GIC are evaluated because their chemical properties are similar to those of $\mathrm{CHX}$ with $\mathrm{AB}$ activity. ${ }^{10-14}$ The $\mathrm{CPC}$, used in this study is a cationic QAC and an antiseptic. ${ }^{15-16}$

One of the most important advantages of GICs is the property of fluoride release. The fluoride ion $\left(\mathrm{F}^{-}\right)$can increase the ambient $\mathrm{pH}$ and prevent acidity by inhibiting the carbohydrate metabolism of the surrounding bacteria. This process is called buffering and is believed to be useful in the prevention of dental caries in future. ${ }^{17}$ It is stated that $\mathrm{AB}$ agents alter the physical properties of the glass ionomer and even reduce $\mathrm{F}^{-}$release and that the interaction between cationic molecules and $\mathrm{F}^{-}$ causes less soluble salt precipitation. Therefore, studies aim to achieve the $\mathrm{F}^{-}$releasing ability of the modified GIC similar to that of the original GIC. ${ }^{18}$

When an $\mathrm{AB}$ agent is added to contents GIC, its physical and chemical properties may weaken. During the curing process of the material, it is possible to shorten the initial period of the curing reaction by applying heat with a light-emitting diode (LED), thus keeping the process, in which it is susceptible to moisture, as short as possible. This aids in to preventing potential weakening of the physical and chemical properties of GIC after AB addition and to further strengthen its existing properties. ${ }^{19}$

The aim of this research was to evaluate $\mathrm{F}^{-}$ release of CPC added conventional GIC under the effect of heat application.

\section{MATERIALS AND METHODS}

In this study, 20 GIC samples (3M ESPE-Ketac ${ }^{\mathrm{TM}}$ Molar Easymix), with and without 5\% CPC (Amresco, Ohio, USA), were used to prepare discs with $10 \mathrm{~mm}$ diameter and $2 \mathrm{~mm}$ thickness. The experimental group comprised GIC combined with $5 \%$ CPC in the powder form weighed using microbalances. Heat $(\mathrm{H})$ generated by LED $(3 \mathrm{M}$ ESPE, Germany) was applied to 10 samples for 60 seconds whereas no heat $(\mathrm{NH})$ was applied to the 10 samples. The sample discs were placed in plastic cylindrical containers of diameter $32 \mathrm{~mm}$, and height $50 \mathrm{~mm}$, which contained $5 \mathrm{ml}$ deionized water ( $\mathrm{pH}$ of approximately 7). The samples were incubated at $37^{\circ} \mathrm{C}$ in the oven (Nüve-FN 500). Solutions of $100 \mathrm{ppm}, 10 \mathrm{ppm}, 1 \mathrm{ppm}, 0.1 \mathrm{ppm}$, and $0.01 \mathrm{ppm}$ were prepared by diluting $100 \mathrm{ppm}$ of standard fluoride solution (Thermo Orion, Indonesia) with deionized water. A calibration procedure was performed on the $\mathrm{F}^{-}$selective electrode (Thermo Orion, Indonesia) before measurement, and the values obtained by measuring these standards were recorded. To measure $\mathrm{F}^{-}$in the test samples, GIC discs were transferred into a new plastic tube and put into a drying-oven by adding $5 \mathrm{ml}$ deionized water; 0.5 $\mathrm{ml}$ ionic strength stabilizing total ionic strength 
adjustment buffer (TISAB) III solution (Therme Orion) was added to the liquid of the other $5 \mathrm{ml}$ test sample. Fluoride measurements were performed using an ion meter (Thermo Orion, Indonesia) at room temperature. Cumulative fluoride release values on the $1^{\text {st }}, 7^{\text {th }}, 15^{\text {th }}$ and $30^{\text {th }}$ days were observed. Calibration curves were generated by calculating the data obtained with the known standard values. The data obtained from the test samples were calculated according to this curve. The results were evaluated as $\mu \mathrm{g} / \mathrm{mm} 2$ after calculating the amount of $\mathrm{F}^{-}$released from the unit area on the sample surface.

\section{Statistical Evaluation}

Statistical Package for Social Sciences [(SPSS) 17.0 Windows (SPSS Inc. Chicago, Ill., USA)] was used for statistical evaluation. Two-way ANOVA and Fisher's LSD test were used for repeated measurements in statistical evaluation ( $\mathrm{p}<0.05)$. The confidence interval was set at $95 \%$.

\section{RESULTS}

Interactions among the time, at which $\mathrm{F}^{-}$release was recorded, application of heat and the study groups exhibited statistically significant values $(\mathrm{p}<0.01$, Table 1).

Table 1. Interaction effects of repeated measurements of two-way ANOVA

\begin{tabular}{lccccc}
\hline & $\begin{array}{c}\text { Type III sum } \\
\text { squares }\end{array}$ & df & Mean square & F & p value \\
Time & 2.687 & 3 & 0.896 & 436.279 & $\boldsymbol{p}<\boldsymbol{0 . 0 0 1}$ \\
Time-Group & 0.16 & 3 & 0.005 & 2.593 & 0.063 \\
Time-Heating & 0.147 & 3 & 0.049 & 23.946 & $\boldsymbol{p}<\boldsymbol{0 . 0 0 1}$ \\
Time-Group-Heating & 0.70 & 3 & 0.023 & 11.421 & $\boldsymbol{p}<\boldsymbol{0 . 0 0 1}$ \\
\hline
\end{tabular}

When $\mathrm{F}^{-}$release values on the $1^{\text {st }}, 7^{\text {th }}, 15^{\text {th }}$ and $30^{\text {th }}$

the30th day, the increase in fluoride release was days were compared between the $\mathrm{NH}$ control and experimental groups, no statistically significant difference was found $(\mathrm{p}>0.05)$ on the $1^{\text {st }}(\mathrm{p}=0.33)$, $7^{\text {th }}(\mathrm{p}=0.14)$ and $15^{\text {th }}(\mathrm{p}=0.77)$ days; however, on statistically significant in the experimental group compared with that in the control group $(\mathrm{p}=0.01$; $\mathrm{p}<0.05$; Table 2).

Table 2. Differences between non-heated control and non-heated experimental groups at different time periods

\begin{tabular}{|c|c|c|c|c|}
\hline & $\begin{array}{c}1^{\text {st day }} \text { day } \\
\text { mean } \pm \text { sd }\end{array}$ & $\begin{array}{c}7^{\text {th }} \text { day } \\
\text { mean } \pm \text { sd }\end{array}$ & $\begin{array}{l}15^{\text {th }} \text { day } \\
\text { mean } \pm \text { sd }\end{array}$ & $\begin{array}{c}30^{\text {th }} \text { day } \\
\text { mean } \pm \text { sd }\end{array}$ \\
\hline Control (n=5) & $0.05 \pm 0.01$ & $0.20 \pm 0.03$ & $0.25 \pm 0.04$ & $0.36 \pm 0.05$ \\
\hline Experimental $(n=5)$ & $0.08 \pm 0.02$ & $0.28 \pm 0.06$ & $0.38 \pm 0.09$ & $0.56 \pm 0.13$ \\
\hline p value & 0.33 & 0.14 & 0.77 & 0.01 \\
\hline
\end{tabular}

*Significantly different values were obtained between control and experimental groups on the 30th day $(\mathrm{p}=0.01)$.

When changes between the $\mathrm{H}$ control and experimental groups were evaluated, it was found that the values were statistically significant (Table $3)$ on the $1^{\text {st }}(\mathrm{p}=0.026 ; \mathrm{p}<0.05), 7^{\text {th }}(\mathrm{p}=0.001 ; \mathrm{p}$ $<0.01), 15^{\text {th }}(\mathrm{p}=0.005 ; \mathrm{p}<0.01)$ and $30^{\text {th }}(\mathrm{p}=$ $0.028 ; \mathrm{p}<0.05)$ days. At all these times, more $\mathrm{F}^{-}$ was released in the control group than in the experimental group. Significantly higher values were observed after the $\mathrm{H}$ procedures than after the $\mathrm{NH}$ procedures on the $1^{\text {st }}, 7^{\text {th }}, 15^{\text {th }}$ and $30^{\text {th }}$ days for the control (for all; $p<0.001$, Table 4) and on the $1^{\text {st }}(\mathrm{p}<0.001), 7^{\text {th }}(\mathrm{p}=0.003), 15^{\text {th }}(\mathrm{p}=0.011)$ and $30^{\text {th }}$ days $(\mathrm{p}=0.029)$ for the experimental groups, individually (Table 5).

Table 3. Differences between heated control and heated experimental groups at different time periods

\begin{tabular}{llccc}
\hline & $\mathbf{1}^{\text {st }}$ day & $\mathbf{7}^{\text {th }}$ day & $\mathbf{1 5}^{\text {th }}$ day & $\mathbf{3 0}^{\text {th }}$ day \\
mean \pm sd & mean \pm sd & mean & sd \\
Control $(\mathbf{n = 5 )}$ & $0.26 \pm 0.06$ & $0.68 \pm 0.10$ & $0.80 \pm 0.11$ & $0.93 \pm 0.07$ \\
Experimental $(\mathbf{n = 5})$ & $0.20 \pm 0.04$ & $0.47 \pm 0.12$ & $0.58 \pm 0.15$ & $0.75 \pm 0.19$ \\
$\boldsymbol{p}$ value & $\mathbf{0 . 0 2 6}$ & $\mathbf{0 . 0 0 1}$ & $\mathbf{0 . 0 0 5}$ & $\mathbf{0 . 0 2 8}$ \\
\hline
\end{tabular}

*Significant differences were found between control and experimental groups on the 1 st $(\mathrm{p}<0.05), 7^{\text {th }}(\mathrm{p}<0.01), 15$ th $(\mathrm{p}<0.01)$ and 30 th days $(\mathrm{p}<0.05)$. 
Table 4. Time-dependent variation in fluoride release in control groups

\begin{tabular}{|c|c|c|c|c|c|}
\hline & 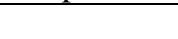 & & & & $p$ value \\
\hline & $\begin{array}{c}1^{\text {st day }} \text { dan } \\
\text { meand }\end{array}$ & $\begin{array}{c}7^{\text {th }} \text { day } \\
\text { mean } \pm \text { sd }\end{array}$ & $\begin{array}{c}15^{\text {th }} \text { day } \\
\text { mean } \pm \text { sd }\end{array}$ & $\begin{array}{c}3^{\text {th }} \text { day } \\
\text { mean } \pm \text { sd }\end{array}$ & $p<0.001$; for all comparisons \\
\hline Heated & $0.26 \pm 0.06^{\mathrm{A}, \mathrm{a}}$ & $0.68 \pm 0.10^{\mathrm{B}, \mathrm{a}}$ & $0.80 \pm 0.11^{\mathrm{C}, \mathrm{a}}$ & $0.93 \pm 0.07^{\mathrm{D}, \mathrm{a}}$ & $\left(p^{A-B, A-C, A-D, B-C, B-D, C-D}<0.01\right)$ \\
\hline $\begin{array}{l}\text { Non- } \\
\text { heated }\end{array}$ & $0.05 \pm 0.01^{\mathrm{E}, \mathrm{b}}$ & $0.20 \pm 0.03^{\mathrm{F}, \mathrm{b}}$ & $0.25 \pm 0.04^{\mathrm{G}, \mathrm{b}}$ & $0.36 \pm 0.05^{\mathrm{H}, \mathrm{b}}$ & $\begin{array}{c}p<0.001 ; \text { for all comparisons } \\
\left(P^{E-F, E-G, E-H, F-G, F-H, G-H}<0.01\right)\end{array}$ \\
\hline
\end{tabular}

Table 5. Time dependent alterations in fluoride release for experimental group

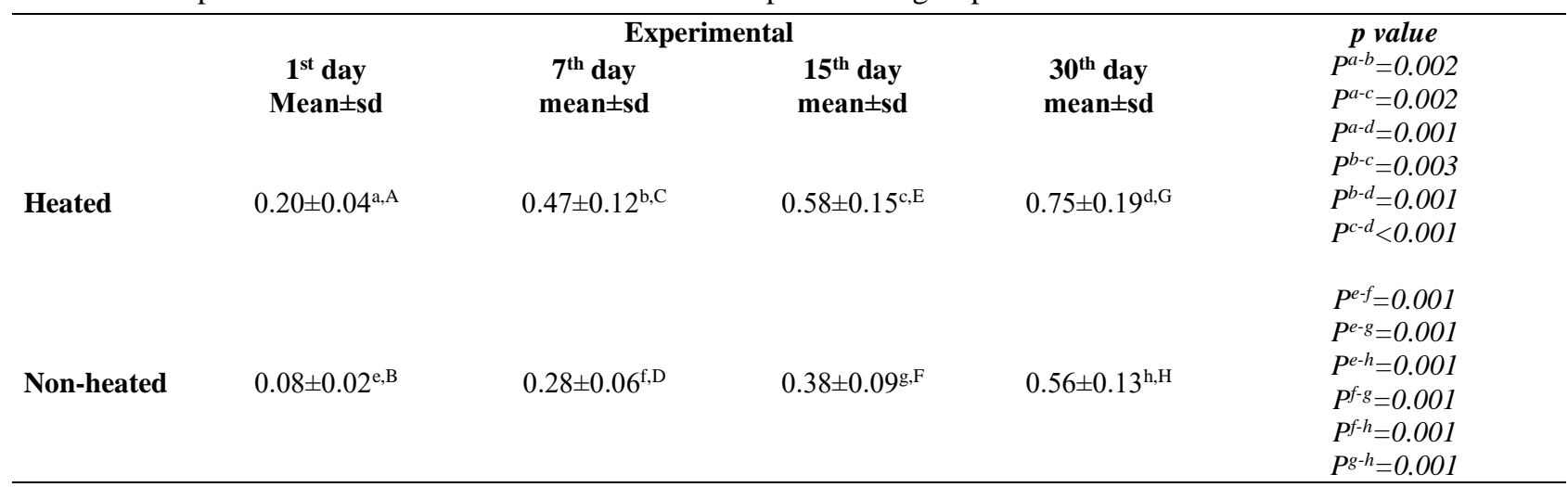

*Statistically significant increase was observed in heated experimental groups from day 1st to 30th (p<0.01).

*The fluoride release in the experimental group increased at a statistically significant level from day 1 st to 30 th with the application of heat (pA$\mathrm{B}<0.001, \mathrm{pC}-\mathrm{D}=0.003, \mathrm{pE}-\mathrm{F}=0.011, \mathrm{pG}-\mathrm{H}=0.029, \mathrm{p}<0.05)$.

There was a statistically significant increase in $\mathrm{F}^{-}$ release from days 1 to day 30 in $\mathrm{NH}$ and $\mathrm{H}$ control groups ( $\mathrm{p}<0.001$; Table 4) and experimental groups (Table 5, Figure 1).

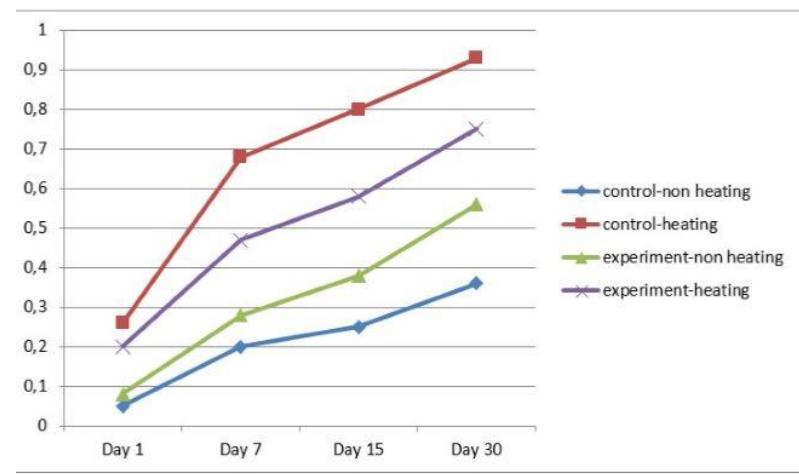

Figure 1. Time dependent alterations in fluoride release in all groups

\section{DISCUSSION}

Heating of samples in the control and experimental groups showed an increased $\mathrm{F}^{-}$release pattern. The fluoride release from GIC containing 5\% CPC on heating for 60 seconds could have acceptable increased values for up to 30 days. McComb,Ericson, ${ }^{20}$ DeSchepper et al. ${ }^{21}$ and Vermeersch et $a .^{22}$ suggested that GIC is antimicrobial because of $\mathrm{F}^{-}$release and/or acidity, but the results of previous investigations about the $\mathrm{AB}$ effects of both $\mathrm{F}^{-}$and low $\mathrm{pH}$ are controversial. $^{23,24}$ Furthermore, the reduction in bacterial counts obtained by placing conventional GICs in cavities is not reliable; therefore, $\mathrm{AB}$ agent-modified GICs would provide an alternative approach. ${ }^{10,11,25}$ The combination of GICs and AB agents, particularly QACs, has been studied in previous studies..$^{11,12,26}$ However, it has been pointed out that the $\mathrm{AB}$ agents alter the physical properties of the glass ionomer. ${ }^{27}$ The interaction between the cationic molecules and $\mathrm{F}^{-}$ions has been reported to cause less soluble salt precipitation. Thus, studies aim to achieve a $\mathrm{F}^{-}$ releasing ability of the modified GIC, similar to that of the original GIC. . $^{12,14,18}$

In experimental studies, ion-selective electrodes are widely used in the analysis of $\mathrm{F}^{-}$ions, because they are practical to use and yield accurate results when used in accordance with the rules. ${ }^{18,28,29}$ Total ionic strength adjustment buffer solution is used in the studies on $\mathrm{F}^{-}$ion analysis for GICs. The buffer solution is added to control $\mathrm{pH}$ and prevent the formation of $\mathrm{F}^{-}$ion complex structure..$^{28,29}$

In the $\mathrm{NH}$ control and experimental groups in our study, although more $\mathrm{F}^{-}$was released in the experimental group at all the times, only the value 
on the $30^{\text {th }}$ day was statistically significant. The fluoride release in the experimental and control groups increased by a statistically significant level over time. Tüzüner et al. ${ }^{30}$ evaluated the amount of $\mathrm{F}^{-}$ions released on the $1^{\text {st }}, 7^{\text {th }}, 15^{\text {th }}$ and $30^{\text {th }}$ days in an experimental group using a mixture of Fuji IX, Ketac Molar powder, 2.5\% CHX, and 2.5\% CT powder and in the control group using Fuji IX and Ketac Molar with no AB agent. As a result, less $\mathrm{F}^{-}$ ions were released in the experimental groups that were combined with an $\mathrm{AB}$ agent at all the times compared with the control group, but this did not cause a statistically significant difference. In addition, there was a decrease in the $\mathrm{F}^{-}$ion release in all the groups over time. Elsaka et al. ${ }^{31}$ investigated the cumulative $\mathrm{F}^{-}$release and $\mathrm{AB}$ properties of modified GIC on the $1^{\text {st }}, 7^{\text {th }}$ and $28^{\text {th }}$ days in their study, in which they added ABeffective titanium-dioxide ( $\mathrm{TiO} 2)$ nanoparticles to conventional GIC. Similar release patterns were observed between the control group excluding titanium dioxide and experimental group. The highest release was observed during the first 24 hours, and the values declined over time. There was no statistically significant difference between the experimental and control groups in terms of the cumulative $\mathrm{F}^{-}$release pattern. Hoszek and Ericson ${ }^{18}$ found that $\mathrm{F}^{-}$release was lower in the experimental group than in the control group on addition of $10 \% \mathrm{CHX}$ to GIC. However, they reported no statistically significant difference between the experimental and control groups in terms of $\mathrm{F}^{-}$ion release levels $(\mathrm{p}>0.05)$ and predicted that poorly soluble salt precipitates resulted from the interaction of cationic molecules and $\mathrm{F}^{-}$ions resulting in this situation. The lack of statistically significant differences between the experimental and control groups in these three studies is consistent with the fact that the $\mathrm{F}^{-}$release values on the $7^{\text {th }}$ and $15^{\text {th }}$ days in this study do not result in a statistically significant difference between the control and experimental groups; conversely, the decreasing $\mathrm{F}^{-}$release values over time and increased $\mathrm{F}^{-}$release in the control group contradicted the results of this study. Hu et al. ${ }^{32}$ found that the $\mathrm{F}^{-}$release values of GIC modified with epigallocatechin-3-gallate (EGCG) and CHX did not show any significant difference between the control and experimental groups, and reported that $\mathrm{F}^{-}$release was the highest in the GIC + CHX group and lowest in the control group at the $24^{\text {th }}$ hour after hardening, and this was parallel with the higher $\mathrm{F}^{-}$ release in the experimental group in our study. All the groups showed a decrease toward the $7^{\text {th }}$ day. However, the $\mathrm{F}^{-}$values on the $7^{\text {th }}$ day were measurable. The decreasing $\mathrm{F}^{-}$values contradicted the results of our study.

When we evaluated the effect of heat application on the groups in terms of the $\mathrm{F}^{-}$release, the values in the control group were higher than those in the experimental group at a statistically significant level at all the times. As in the $\mathrm{NH}$ experimental and control groups, there was a significantly increasing $\mathrm{F}^{-}$release over time in the $\mathrm{H}$ groups. On analyzing the control and experiment groups individually, we found that heat application caused significantly more $\mathrm{F}^{-}$release. As far as we have reviewed the previous literature, there have been no studies investigating how heat application affects $\mathrm{F}^{-}$release in GIC. However, there have been many studies exhibiting how the physical and chemical properties of conventional GICs and other dental materials are affected by radiant heat application. ${ }^{33-35}$ Tolidis et al. ${ }^{34}$ examined the effects of radiant heat and ultrasonic heat applied by LED on GIC in their study with working groups. No heat treatment was applied in the control group, and radiant heat with LED was applied for 2 minutes and ultrasound for 55 seconds in the experimental group. The fluoride release values on the $7^{\text {th }}, 14^{\text {th }}$ and $28^{\text {th }}$ days was assessed. The radiant heat applied during hardening reduces the release of $\mathrm{F}^{-}$. Furthermore $\mathrm{F}^{-}$release decreased and surface hardness increased after ultrasonic treatment. Rafeek ${ }^{35}$ applied only heat and heat along with pressure, both on conventional and resin-modified GICs and investigated the effect of these treatments on some physical characteristics of GICs and $\mathrm{F}^{-}$release. The presence of heat was found to produce no significant result on conventional GIC; however, it reduced the release of $\mathrm{F}^{-}$in resin-modified GIC. It is thought that the $\mathrm{F}^{-}$release decreases whereas the physical properties of the resin modified by the heat application strengthen in accordance to the study limitations. 
When we compared the unmodified control group of our study with all those of the studies mentioned above, we found that the reduced $\mathrm{F}^{-}$ release caused by heat application was not consistent with the results of our study. It may be considered that the differences in all $\mathrm{F}^{-}$release patterns in the $\mathrm{NH}$ control/ experimental and $\mathrm{H}$ control groups that contradict with the literature are owing to the experimental variables in in-vitro studies, such as the internal structure of the material, including the composition, geometric structure, solubility, and porosity of the material used, the powder/ liquid ratio during the preparation, the amount and size of the sample, ambient temperature, surface applications, such as Vaseline or varnish on the material, ambient $\mathrm{pH} /$ volume, different measurement methods, and other unknown factors. ${ }^{18,25,36}$

However, compared with the previous studies, it can be considered that heat application may increase $\mathrm{F}^{-}$release from the GIC combined with antibacterial materials, and this may be beneficial and promising for future studies.

\section{CONCLUSIONS}

As a result of our research conducted under invitro conditions, a significant increase in fluoride release in both conventional and GICs modified with an antibacterial agent at all time periods, as a result of heat application, can be considered promising for the fluoride release levels of GIC materials and future research. According to the results, when GIC is used in the ART techniques 60 seconds of heat administration will reduce the decay level occurring at the bottom of the face and teeth with binding surface are promising in clinical be said.

\section{ACKNOWLEDGEMENTS}

None

\section{CONFLICT OF INTEREST}

None

\section{Antibakteriyel Ajan İlave Edilen Cam İyonomer Simanda Isı Uygulamasının Florür Salımına Etkisi $\ddot{O} Z$}

Amaç: Çalışmanın amacı konvansiyonel yapıda olan ve $\% 5$ cetylpryridium chloride (CPC) ile kombine edilen cam iyonomer simanda (CIS) florür $\left(F^{-}\right)$salımına, ısının etkisini dĕgerlendirmektir. Gereç ve Yöntemler: \%5 cetylpryridium chloride (CPC) ile kombine edilen deney ve \%5 CPC içermeyen kontrol grubundan oluşan yirmi adet ( $n=5$; her grupta) CISS örneği hazırlandl. Örneklerden 10 tanesine isı uygulanmadı (IU), diğer 10 tanesine ise 60 sn Light Emitting Diode (LED) ışık kaynağı ile oluşturulan ısı etkisi (IE) altında uygulama yapıldı. Bir, 7, 15 ve 30. günlerdeki $F^{-}$salımı gözlendi. Karşılaştırmalar için iki yönlü ANOVA ve Fisher's LSD testinin tekrarlanan ölçümleri kullanıldı $(p<0,05)$. Bulgular: Florür salımının değerlendirildiği grup, ısı ve zaman değişkenleri arasındaki etkileşimler analiz edildi $(p<0,001)$. Bir, 7 ve 15. günlerdeki IU kontrol ve deney gruplarında $F^{-}$salımı açısından anlamlı bir fark yoktu, ancak 30. günde deney grubunda anlamlı bir $F^{-}$salımı $\operatorname{vard}_{\imath}(p=0,01)$. Isı etkisi altında kontrol grubu için 1 $(p=0,026), 7(p=0,001), 15(p=0,005)$ ve 30. $(p=0,028)$ günlerde deney grubuna klyasla anlaml olarak daha yüksek değerler elde edildi. Hem IU hem de IE altındaki her iki grupta da 1 ila 30 gün arasında anlamlı olarak artan değerler elde edildi ( $p<0,001)$. Sonuç: Isı etkisinin kontrol ve deney gruplarında $F^{-}$salımını arttırdığı gözlendi. 60 sn ısı uygulanan \%5 CPC eklenen CISS $F^{-}$düzeyinde 30. güne kadar kabul edilebilir bir artış gözlendi. Isı uygulaması; antibakteriyel eklenmiş CIS'lerin florür salım düzeyleri için ümit vaat edicidir.

Anahtar kelimeler: Anti-bakteriyel ajanlar, cam iyonomer siman, florürler, isitma.

\section{REFERENCES}

1. Ismail AI. Reactor paper: minimal intervention techniques for dental caries. J Public Health Dent 1996; 56: 155-160.

2. Mjor IA, Gordan VV. A review of atraumatic restorative treatment (ART). Int Dent J 1999; 49:27-131.

3. Blinkhorn AS, Davies RM. A continued need worldwide. Int Dent J 1996; 46: 119-125.

4. Pilot T. Introduction-ART from global perspective. Community Dent Oral Epidemiol 1999; 27: 421-422.

5. Chkir AF, Salem KB, Volu KA. Atraumatic restorative treatment and glass ionomer sealants in Tunisian children: survival after 3 years. East Mediter Health J 2002; 23: 200-204.

6. van Amerongen WE. Dental caries under glass ionomer restorations. J Public Health Dent 1996; 56: 150-154. 
7. Gu YW, Yap AU, Cheang P, Khor KA. Effects of incorporation of $\mathrm{HA} / \mathrm{ZrO}(2)$ into glass ionomer cement (GIC). Biomaterials 2005; 26:13-20.

8. Yli-Urpo H, Lassila LV, Narhi $T$, Vallitu PK. Compressive strength and surface characterization of glass ionomer cements modified by particles of bioactive glass. Dent Mater 2005; 21: 201-209.

9. Dabsie F, Gregoire G, Sixou M, Sharrock P. Does strontiumplay a role in the cariostatic activity of glass ionomer? Strontium diffusion and antibacterial activity. J. Dent 2009; 37: 554-559.

10. Botelho MG. Inhibitory effects on selected oral bacteria of antibacterial agents incorporated in a glass ionomer cement. Caries Res 2003; 37: 108-114.

11. Ribeiro J, Ericson D. In vitro antibacterial effect of chlorhexidine added to glass-ionomer cements. Scand J Dent Res 1991; 99: 533-540.

12. Sanders BJ, Gregory RL, Moore K, Avery DR. Antibacterial and physical properties of resin modified glass-ionomers combined with chlorhexidine. J Oral Rehabil 2002; 29: 553-558.

13. Botelho MG. The antimicrobial activity of a dentin conditioner combined with antibacterial agents. Oper Dent 2005; 30: 75-82.

14. Botelho MG. Compressive strength of glass ionomer cements with dental antibacterial agents. Sadj 2004; 59: 51-53.

15. Albert-Kiszely A, Pjetursson BE, Salvi GE, Witt J, Hamilton A, Persson GR, Lang NP. Comparison of the effects of cetylpyridinium chloride with an essential oil mouth rinse on dental plaque and gingivitis - a sixmonth randomized controlled clinical trial. J Clin Periodontol 2007; 34: 658-67.

16. Haps S, Slot DE, Berchier CE,Van der Weijden GA. The effect of cetylpyridinium chloride-containing mouth rinses as adjuncts to toothbrushing on plaque and parameters of gingival inflammation: a systematic review. Int J Dent Hyg 2008; 6: 290-303.

17. Nicholson JW, Czarnecka B, Limanowska-Shaw H. The long-term interaction of dental cements with lactic acid solutions. J Mater Sci Mater Med 1991; 10: 449452.

18. Hoszek A, Ericson D. In vitro fluoride release and the antibacterial effect of glass ionomers containing chlorhexidine gluconate. Oper Dent 2008; 33: 696-701. 19. Prabhakar AR, Prahlad D, Kumar SR. Antibacterial activity, fluoride release, and physical properties of an antibiotic- modified glass ionomer cement. Pediatr Dent 2013; 35: 411-415.

20. McComb D, Ericson D. Antimicrobial action of new, proprietary lining cements. J Dent Res 1987; 66: 10251028.

21. DeSchepper EJ, White RR, von der Lehr W. Antibacterial effect of glass ionomers. Am J Dent 1989; 2: 51-56.

22. Vermeersch G, Leloup G, Delmée M, Vreven J. Antibacterial activity of glassionomer cements, compomers and resin composites: relationship between acidity and material setting phase. J Oral Rehabil 2005; 32: 368-374.

23. Tam LE, Chan GP, Yim D. In vitro caries inhibition effects by conventional and resin-modified glassionomer restorations. Oper Dent 1997; 22: 4-14.

24. Miller BH, Komatsu H, Nakajima H, Okabe $T$. Effect of glass ionomer manipulation on early fluoride release. Am J Dent 1995;8: 182-186.

25. Takahashi Y, Imazato S, Kaneshiro AV, Ebisu S, Frencken JE, Tay FR. Antibacterial effects and physical properties of glass-ionomer cements containing chlorhexidine for the ART approach. Dent Mater 2006; 22: 647-652.

26. Imazato S. Antibacterial properties of resin composites and dentin bonding systems. Dent Mater 2003; 19: 449-457.

27. Towler MR, Bushby AJ, Billington RW, Hill RG. A preliminary comparison of the mechanical properties of chemically cured and ultrasonically cured glass ionomer cements, using nano-indentation techniques. Biomaterials 2001; 22: 1401-1406.

28. Asmussen E, Peutzfeldt A. Long-term fluoride release from a glass ionomer cement, a compomer, and from experimental resin composites. Acta Odontol Scand 2002; 60: 93-97.

29. Lucas ME, Arita K, Nishino M. Toughness, bonding and fluoride-release properties of hydroxyapatite-added glass ionomer cement. Biomaterials 2003; 24: 3787 3794.

30. Tüzüner T, Kuşgöz A, Er K, Taşdemir T, Buruk K, Kemer B, Saray O. Antibacterial activity and physical properties of conventional glass-ionomer cements containing chlorhexidine diacetate/ cetrimide mixtures. J Esthet Rest Dent 2011; 23: 46-55.

31. Elsaka SE, Hamouda IM,Swain MV. Titanium dioxide nanoparticles addition to a conventional glass- 
ionomer restorative: influence on physical and antibacterial properties. J Dent 2011; 39: 589-598.

32. Hu J, Du X, Huang C, Fu D, Ouyang X,Wang Y. Antibacterial and physical properties of EGCGcontaining glass ionomer cements. J Dent 2013; 41: 927 934.

33. Dionysopoulos D, Tolidis K, Gerasimou P, Sfeikos T. Effect of Three Clinical Curing Treatments on Fluoride Release and Surface Hardness of GlassIonomer Cements. Int J Periodontics Restorative Dent 2017;37:197-203.
34. Tolidis K, Dionysopoulos D, Gerasimou P, Sfeikos T. Effect of radiant heat and ultrasound on fluoride release and surface hardness of glass ionomer cements. J Appl Biomater Funct Mater 2016 2;14:463-469.

35. Rafeek RN. The effects of heat treatment on selected properties of a conventional and a resin-modified glass ionomer cement. J Mater Sci Mater Med 2008; 19: 1913 1920.

36. De Witte AM, De Maeyer EA, Verbeeck RM, Martens LC. Fluoride release profiles of mature restorative glass ionomer cements after fluoride application. Biomaterials 2000; 21: 475-482. 